\title{
Å gi informasjon om sårbarhet
}

Risiko er et sentralt begrep i medisinen. For leger er ordet og dets innhold hverdagslig, ofte tallfestet, alltid kjølig og taust til stede. Når vi snakker med pasienter om risiko, bør vi oversette det til sårbarhet. Ikke nødvendigvis i samtalen, men inni oss, som en påminnelse om at nå berører vi noe truende. Sårbarhet er et videre begrep, mer eksistensielt. Med hensyn til risiko tenker legen bare på pasienten. Sårbar, derimot, er legen sammen med pasienten. Sårbarhet er et fellesgode vi trenger i kommunikasjon med pasienter. Når vi erkjenner og tåler vår egen sårbarhet, angsten for ikke å gjøre en god nok jobb, få kritikk, eller forårsake skade, er vi i berøring med pasientens sårbarhet og eksistensielle vilkår. En ung norsk kardiolog skriver godt om dette i en avhandling fra 2010 (1). Hun påpeker at eksistensielle perspektiver i samtaler med alvorlig syke er nødvendig både for pasienten og for legen. La det likevel være sagt at selv om sårbarhet er noe vi har felles, er den sikreste vei til å bomme at vi baserer vår kommunikasjon på egne ideer og erfaringer om hva som vil være det verste for den pasienten vi står overfor. Vi må lete frem forskeren i oss: Hvem er dette mennesket, og hva tenker han?

I dette nummer av Tidsskriftet er det en artikkel om hva pasienter som har overlevd kreft vet om senfølger av tilstanden og behandlingen (2). Det dreier seg om unge voksne som fikk diagnosen akutt lymfatisk leukemi som barn i perioden 1970-2002. Forfatterne finner at flertallet av disse menneskene ikke kjenner til noen av de alvorlige senfølgene. Mange spørsmål aktualiseres: Bør pasienter være informert om risiko og prognoser? Hvilken informasjon skal de få? Når og hvordan skal den gis?

At slike spørsmål i det hele tatt stilles, viser at å være informert ikke er et ubetinget gode. Mange klinikere har erfart uventet negative reaksjoner fra pasienter på informasjon gitt $\mathrm{i}$ beste mening og med et ønske om å være ærlig (3). En kronikk som første gang ble publisert i Aftenposten (4), senere i et tosifret antall nordiske aviser, er et uttrykk for negative pasienterfaringer og kan forstås som at leger bør holde tilbake prognostisk informasjon. Slike erfaringer tyder på at den nødvendige ærlighet i slike spørsmål ikke er ledsaget av tilstrekkelig medfølelse og evne til å bidra med realistisk håp.

Det finnes også kulturer der det er uhørt å fortelle den syke selv hvordan det kommer til å gå hvis prognosen er dårlig. Derfor finnes ikke et utvetydig svar på spørsmålet om hvor mye pasienter flest bør få vite. Derimot finnes et klart svar på hva den enkelte pasient bør få vite, og det svaret må nennsomt hentes hos pasienten selv. En grunn leger oppgir for å være forsiktig med å gi en prognose, er at man ikke kan overføre kunnskap om grupper til den enkelte pasient. Likedan kan man ikke forutsi hvilken informasjon én pasient vil ha basert på hva de fleste vil ha. Her er vi ved kjernen: Det å gi informasjon er en toveis prosess. Når legen formidler sin kunnskap til pasienten, må det bygge på en forståelse av pasientens utgangspunkt og en underforstått tillatelse (5).

Dessverre er leger altfor lite skolert i hvordan de skal gi informasjon. Rett nok gis basisundervisning under studiet i Norge, men oppgaven er kompleks og i sykehus gis ingen systematisk veiledning i denne ferdigheten etter studiet. Den blir altså ikke tatt alvorlig i den norske spesialisthelsetjenesten. På et vis gjenspeiles det i den ellers utmerkede artikkelen til Ellen Ruud og medarbeidere (2). Forfatterne etterlyser mer forskning om kommunikasjons- metoder, men ikke én av referansene viser til den omfattende litteraturen vi har på feltet, noe som strengt tatt også rammer Tidsskriftets redaksjonelle behandling. Når det gjelder samtale med alvorlig syke, finnes kortfattet glimrende litteratur (6), men man må ikke tro at man kan lese seg til kommunikasjonsferdigheter. Å utvikle dem er parallelt til å utvikle kirurgisk kompetanse. Det finnes noen norske kurstilbud, og det finnes et veletablert engelskspråklig tilbud som man kan finne via hjemmesiden til den europeiske organisasjonen European Association of Communication in Healthcare (7).

Mange leger kjenner heller ikke til norsk forskning på feltet. Jan Frich ved Universitetet i Oslo har for eksempel studert hvordan pasienter med familiær hyperkolesterolemi forstår sin risiko. De tenker ikke i tall med konfidensintervaller, men utvikler sin forståelse av personlig risiko i en trinnvis prosess der de først vurderer egen familiehistorie og hvordan den peker mot sannsynlig alder for å pådra seg hjertesykdom. Dernest justerer de sin risikovurdering idet de sammenlikner seg med andre i familien med henblikk på kjønn, livsstil og annet (8). En fersk norsk doktoravhandling handler om genetisk veiledning blant pakistansknorske familier (9). Torunn Arntsen Sajjad beskriver legekontoret som velvillighetens arena, og legene som godt forberedt. Likevel påviser hun hvordan legene i stor grad mislykkes, fordi de færreste gjør forsøk på å skaffe seg innsikt i hva som er viktig for parene som ønsker rådgivning, hvilke forestillinger de har, og hva de mener med vesentlige begreper som «søskenbarn».

Jeg hører ofte kolleger klage over at pasientene ikke husker hva de er blitt fortalt. Vi må innse at årsaken ligger hos oss selv, og det kan vi og våre arbeidsgivere gjøre noe med.

Pål Gulbrandsen

pal.gulbrandsen@medisin.uio.no

Pål Gulbrandsen (f. 1955) er professor i helsetjenesteforskning ved Universitetet i Oslo og seniorforsker ved Akershus universitetssykehus. Forfatter har fylt ut ICMJE-skjemaet og oppgir ingen interessekonflikter.

\section{Litteratur}

1. Schaufel MA. Å dele uvissa og ansvaret. Ein kvalitativ studie av livets grunnvilkår i medisinsk praksis. Doktoravhandling. Bergen: Universitetet i Bergen, 2010.

2. Ruud E, Kanellopoulos A, Widing E et al. Senfølger etter akutt lymfatisk leukemi - hva vet pasientene? Tidsskr Nor Legeforen 2012; 132: 2052-5.

3. Rogg LV, Aasland OG, Graugaard PK et al. Direct communication, the unquestionable ideal? Oncologists' accounts of communication of bleak prognoses. Psychooncology 2010; 19: 1221-8.

4. Johnsen J. Hva bør en lege si til sin pasient? Aftenposten (morgenutgave) 26.3.2012

5. Kristvik E. For whom and for what? Exploring the question of 'informed consent' in treatment decision making processes. Medische Antropologie 2011; 23: $29-43$.

6. Back A, Arnold R, Tulsky J. Mastering communication with seriously ill patients Balancing honesty with empathy and hope. Cambridge: Cambridge University Press, 2009.

7. EACH (European Association of Communication in Healthcare). www.each.eu (13.9.2012)

8. Frich JC, Ose L, Malterud K et al. Perceived vulnerability to heart disease in patients with familial hypercholesterolemia: a qualitative interview study. Ann Fam Med 2006; 4: 198-204

9. Sajjad TA. «Hvis det fødes et sykt barn, hva tror du det skyldes?» En medisinsk antropologisk studie av genetisk veiledning blant pakistansknorske familier. Doktoravhandling. Oslo: Universitetet i Oslo, 2011. 